\title{
INTERPRETASI ELEMEN VERNAKULAR PADA TATA RUANG KAWASAN SEBAGAI IMPLEMENTASI REGIONALISME KRITIS
}

\author{
Sherlly Maulana ${ }^{1}$ dan Suswati
}

Dikirim: 12 November 2013 Disetujui: 20 Januari 2014

\begin{abstract}
Dampak globalisasi di Kawasan Danau Toba telah menyebabkan hilangnya identitas kawasan yang telah mengakibatkan penurunan nilai dan image kawasan. Tujuan penelitian ini adalah menjadikan elemen vernakular sebagai identitas pada tata ruang kawasan, melalui penerapan teori regionalisme kritis. Lokasi penelitian berada di Desa Tongging, Kecamatan Merek, Kabupaten Karo. Tahapan penelitian terdiri dari pengumpulan data melalui arsip literatur tentang vernakular Batak Toba dan survey aktivitas masyarakat Tongging melalui observasi, penyebaran kuesioner, dan wawancara semi-terstruktur, tahap analisis dan sintesis berupa analisis deskriptif kualitatif. Hasil penelitian berupa potensi kawasan yang dapat dikembangkan sebagai identitas kawasan berdasarkan interpretasi elemen vernakular, yaitu: 1) budaya agraris; 2) penataan ruang yang mengadopsi bentuk kampung; 3) budaya gotong royong melalui peningkatan partisipasi aktif masyarakat dalam perbaikan kawasan; dan 4) bentuk arsitektur tropis yang beradaptasi terhadap iklim.
\end{abstract}

\section{Kata kunci: Identitas, Globalisasi, Regionalisme Kritis, Vernakular, Tata Ruang}

\begin{abstract}
The impact of globalization in the area of Lake Toba has led to the loss of regional identity that has resulted in a decrease in the value and image of the region. The purpose of this research is to make the vernacular as the identity element in the spatial region, through the application of the theory of critical regionalism. Location of the study is in Tongging Village, Sub Brand, Karo. Stages of the study consisted of data collection through the archives of vernacular literature and surveys Batak Toba Tongging community activities through observation, questionnaires, and semi-structured interviews, analysis and synthesis in the form of qualitative descriptive analysis. The results of the research is a potential area that can be developed as a regional identity based on the interpretation of vernacular elements, namely: 1) agrarian culture; 2) spatial adopts the village; 3 ) culture of cooperation through increased community participation in neighborhood improvement; and 4) the form of tropical architecture adapted to the climate.
\end{abstract}

Keywords: Identity, Globalization, Critical Regionalism, Vernacular, Spatial

\section{Pendahuluan}

Kawasan Wisata Danau Toba adalah danau tektonik-vulkanik terbesar di dunia dan merupakan salah satu wisata unggulan utama untuk Sumatera Utara, bahkan Indonesia. Globalisasi ekonomi dalam bentuk komersialisasi Danau Toba sebagai konsumsi pariwisata telah mengakibatkan terjadinya perubahan aktifitas ekonomi, terutama di Parapat dan Tuktuk. Perkembangan industri pariwisata yang pesat telah mendorong tumbuhnya areal pemukiman baru di sekitar danau, pengembangan fasilitas akomodasi wisata, seperti hotel

\footnotetext{
${ }^{1}$ Program Studi Arsitektur, FT. Universitas Medan Area
} 
dan restoran, pemanfaatan daerah sepadan danau sebagai area terbangun, dan penurunan kualitas air yang disebabkan oleh limbah cair.

Globalisasi pengetahuan memberikan dampak terhadap penyebaran ide-ide arsitektur yang tidak harmonis dan sesuai dengan lokal konteks. Hal ini dapat diamati dari penggunaan atap datar, gaya arsitektur minimalis dan mediteranian, serta penggunaan material bangunan asbes, kaca, dan alumunium komposit panel.

Dampak globalisasi yang semakin luas di kawasan Danau Toba mengarahkan perkembangan kawasan ke arah homogenitas yang memberikan dampak negatif terhadap identitas/sense of place kawasan. Hilangnya identitas kawasan mengakibatkan penurunan nilai dan image kawasan.

Regionalisme kritis adalah trend kontemporer regionalisme yang muncul sebagai reaksi terhadap universalisasi, homogenitas budaya, dan placeless modernism akibat globalisasi (Frampton, 1983). Strategi utama dari regionalisme kritis adalah untuk menjadi penengah dalam menghadapi dampak peradaban dunia dengan menggunakan elemenelemen yang secara langsung berasal dari keunikan suatu tempat (Frampton, 1983). Regionalisme kritis menguatkan elemen-elemen lokal arsitektur untuk dapat menghadapi globalisasi dan menciptakan konsep-konsep abstrak yang melibatkan suatu sintesa kritis terhadap sejarah dan tradisi setempat serta menginterpretasikannya kembali untuk mendapatkan ekspresi dalam terminologi modern (Frampton, 1983).

Regionalisme kritis memiliki visi bahwa lingkungan buatan mampu beradaptasi dengan kondisi global melalui negosiasi antara lokal dan global. Menurut Mohite (2008), regionalisme kritis memandang bahwa identitas arsitektur ditentukan oleh: 1) tapak dan lokal konteks; 2) Iklim; 3) Kualitas ruang; dan 4) interpretasi elemen vernakular.

Hasil penelitian Maulana (2011), memperlihatkan bahwa adaptasi bangunan di sekitar Kawasan Wisata Danau Toba, terutama bangunan fasilitas wisata, terhadap elemenelemen vernakular masih rendah (41,18\%). Sementara itu, elemen-elemen tradisional yang berkaitan dengan budaya, sejarah, dan tradisi suatu tempat merupakan variabel penting yang sangat berpotensi untuk dikembangkan sebagai identitas kawasan. Interpretasi terhadap sejarah dan tradisi setempat yang dikaitkan dengan kondisi waktu, ruang, dan lingkungan yang berlaku pada saat itu akan menghasilkan suatu bentuk simbiosis baru sebagai bentuk ekspresi arsitektur dalam terminologi modern. Penelitian ini bertujuan untuk menjadikan elemen vernakular sebagai identitas pada tata ruang kawasan, melalui penerapan teori regionalisme kritis.

\section{Metode Penelitian}

\section{Lokasi Penelitian}

Lokasi penelitian berada di Desa Tongging, Kecamatan Merek, Kabupaten Karo, Sumatera Utara (Gambar 1). Lokasi yang dipilih adalah daerah yang dianggap kawasan alternatif sebagai kawasan pengalih yang bertujuan untuk mencegah aglomerasi kegiatan yang ada saat ini di kota Parapat. Desa Tongging, Kabupaten Karo, Sumatera Utara merupakan salah satu tujuan wisata unggulan di Kabupaten Karo, namun belum dikembangkan secara maksimal. 


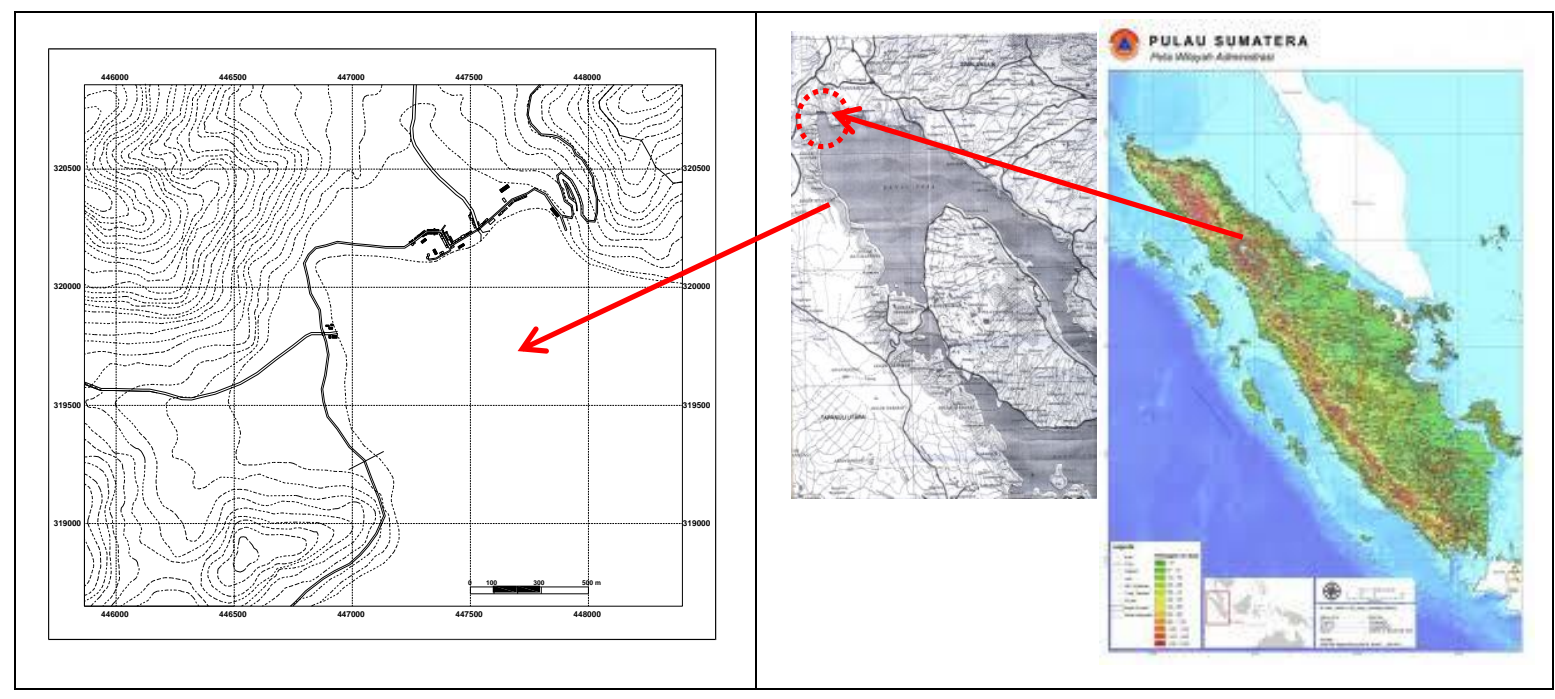

Sumber: Bakosutanal dan Dokumentasi Lapangan, 2011

\section{Gambar 1 Lokasi Penelitian Desa Tongging, Kecamatan Merek, Kabupaten Karo}

\section{Tahapan Penelitian}

Rencana penelitian didesain melalui proses fungsi evaluasi diri dengan metode defamiliarization, yaitu mencari, mengamati, dan mengolah elemen-elemen regional yang ada di tapak untuk mencari hubungan sentimental antara bangunan dan tempat (Tzonis dan Lefaivre, 1990). Proses penelitian akan melewati beberapa tahapan, yaitu: 1) tahap pengumpulan data; 2) tahap analisis dan sintesis; dan 3) tahap kesimpulan berupa rekomendasi rancangan tata ruang kawasan.

Tahap pengumpulan data berupa: 1) arsip literatur tentang vernakular Batak Toba dan 2) survey aktivitas masyarakat Tongging melalui observasi, penyebaran kuesioner, dan wawancara semi-terstruktur. Vernakular Batak Toba menjadi dasar pemikiran penelitian karena mayoritas penduduk Tongging memiliki latar belakang budaya Batak Toba.

Tahap analisis dan sintesis berupa analisis deskriptif kualitatif dengan melakukan pembobotan, skoring, dan penentuan peringkat terhadap variabel yang mempengaruhi vernakular Batak Toba, terdiri dari: 1) mata pencaharian; 2) sistem kekerabatan (kinship); 3) agama dan kepercayaan; dan 4) arsitektur Batak Toba (Nawawiy, dkk, 2004). Hasil analisis meliputi: 1) hasil penilaian potensi masing-masing variabel sebagai identitas kawasan; 2) permasalahan-permasalahan yang mungkin timbul dalam rancangan kawasan untuk masing-masing variabel; dan 3) alternatif solusi yang dapat diambil dalam proses pengambilan keputusan desain.

\section{Hasil dan Pembahasan}

\section{Mata Pencaharian}

Sesuai dengan kondisi lokasi yang didominasi oleh hujan dan kemarau, serta kehidupan flora dan faunanya, maka mata pencaharian pokok penduduk yang digunakan untuk memenuhi kebutuhan hidup sehari-hari adalah bertani. Sistem kehidupan agraris melalui pertanian sangat dominan dalam kehidupan masyarakat tradisional Batak Toba dan Karo. Kegiatan ini selalu terikat dengan kepercayaan saat itu dan menuntut bentuk arsitektur yang sesuai. Hal ini terlihat dengan adanya bangunan penyimpanan hasil pertanian (lumbung) yang disebut Sopo. Bangunan ini juga merupakan simbol konsep 
swadaya dan gotong royong dalam kehidupan masyarakat tradisional Batak Toba sebagai dampak dari sistem kehidupan agraris tersebut.

Kondisi eksisting yang didominasi oleh areal pertanian menjadi potensi lokal yang harus dipertahankan karena merupakan bagian dari kehidupan sosial budaya masyarakat setempat. 86\% penduduk Desa Tongging bermata pencarian petani. Oleh karena itu, aktivitas pertanian dipertahankan dan dimanfaatkan, yaitu dengan menjadikan bagian dari aktifitas/atraksi wisata yang dapat dinikmati oleh wisatawan. Interpretasi budaya agraris dalam kehidupan sosial budaya masyarakat Batak Toba dalam perancangan tata ruang kawasan akan membentuk simbiosis baru yang dicerminkan dalam program aktivitas dan ruang (Gambar 2).

\section{Hubungan kekerabatan (kinship)}

Sistem kekerabatan (kinship) adalah pusat semua interaksi sosial dalam budaya Batak Toba yang hingga saat ini masih berlaku. Masyarakat tradisional Batak Toba menggambarkan hal ini dalam upacara-upacara tradisi dan konsep arsitekturnya, yaitu konsep struktur masyarakat Batak Toba yang disebut Huta (kampung) dan konsep ruma pada bangunan tradisionalnya. (Gambar 3).

\begin{tabular}{|c|c|c|}
\hline \multicolumn{2}{|r|}{ Masyarakat Tradisional Batak Toba } & RTRK Tongging \\
\hline \multirow{2}{*}{$\begin{array}{c}\text { Budaya } \\
\text { Agraris } \\
\text { sebagai } \\
\text { sumber mata } \\
\text { pencaharian }\end{array}$} & $\begin{array}{l}\text { Terikat pada kepercayaan yang berkembang } \\
\text { saat itu, hingga menuntut bentuk-bentuk } \\
\text { arsitektur yang sesuai, seperti bangunan } \\
\text { Sopo }\end{array}$ & $\begin{array}{l}\text { Aktivitas masyarakat setempat } \\
\text { bertani }\end{array}$ \\
\hline & $\begin{array}{l}\text { Konsep hidup swadaya dan gotong royong } \\
\text { menjadi bagian dari sikap dan prinsip hidup }\end{array}$ & $\begin{array}{l}\text { Aktivitas pengunjung difasilitasi } \\
\text { dengan aktivitas berekreasi }\end{array}$ \\
\hline
\end{tabular}

\begin{tabular}{|c|l|}
\hline \multicolumn{2}{|c|}{ Bentuk Simbiosis Baru } \\
\hline \multirow{4}{*}{$\begin{array}{c}\text { Program } \\
\text { Aktivitas }\end{array}$} & $\begin{array}{l}\text { Pemberdayaan masyarakat setempat melalui partisipasi aktif dalam hal peningkatan } \\
\text { aktivitas kegiatan wisata }\end{array}$ \\
\cline { 2 - 3 } & Aktifitas wisata melalui konsep agrowisata berbasis pemberdayaan masyarakat \\
\cline { 2 - 3 } & $\begin{array}{l}\text { Penduduk memenuhi kebutuhan hidupnya sendiri dengan memberdayakan potensi } \\
\text { lokal sebagai bentuk konsep swadaya yang merupakan sikap hidup masyarakat } \\
\text { Batak Toba }\end{array}$ \\
\hline \multirow{3}{*}{$\begin{array}{c}\text { Program } \\
\text { Ruang }\end{array}$} & $\begin{array}{l}\text { Kondisi eksisting tapak yang didominasi oleh areal pertanian akan tetap } \\
\text { dipertahankan seoptimal mungkin }\end{array}$ \\
\cline { 2 - 3 } & $\begin{array}{l}\text { Pemberdayaan masyarakat setempat dalam memperbaiki dan menjaga kualitas } \\
\text { ruang }\end{array}$ \\
\hline
\end{tabular}

\section{Gambar 2 Interpretasi Terhadap Nilai Budaya Agraris Masyarakat Batak Toba}

Pola perkampungan Batak Toba pada umumnya berkelompok membentuk cluster. Terdiri dari berbagai jenis bangunan untuk fungsi yang berbeda-beda. Bangunan rumah tinggal disebut dengan ruma dan rumah tempat penyimpanan hasil pertanian disebut dengan sopo. Ruma adalah rumah untuk fungsi hunian yang dihuni oleh lebih dari satu keluarga, umumnya 5 - 6 keluarga. Bagian dalam ruang tidak memiliki pembatas fisik yang memisahkan antar ruang satu keluarga dengan keluarga lainnya (Gambar 4). Namun, pada 
kenyataannya terdapat pembatas psikologis dan kultural yang tegas di antara ruang tersebut sesuai dengan keyakinan dan adat masyarakat Batak Toba. Seluruh ruang dapat digunakan untuk berbagai fungsi aktivitas komunal, seperti tempat makan, tempat tidur, dan dapur. Rumah dalam masyarakat tradisional Batak Toba merupakan simbol dari hubungan kekerabatan dan cerminan konsep budaya gotong royong dan swadaya dalam masyarakat

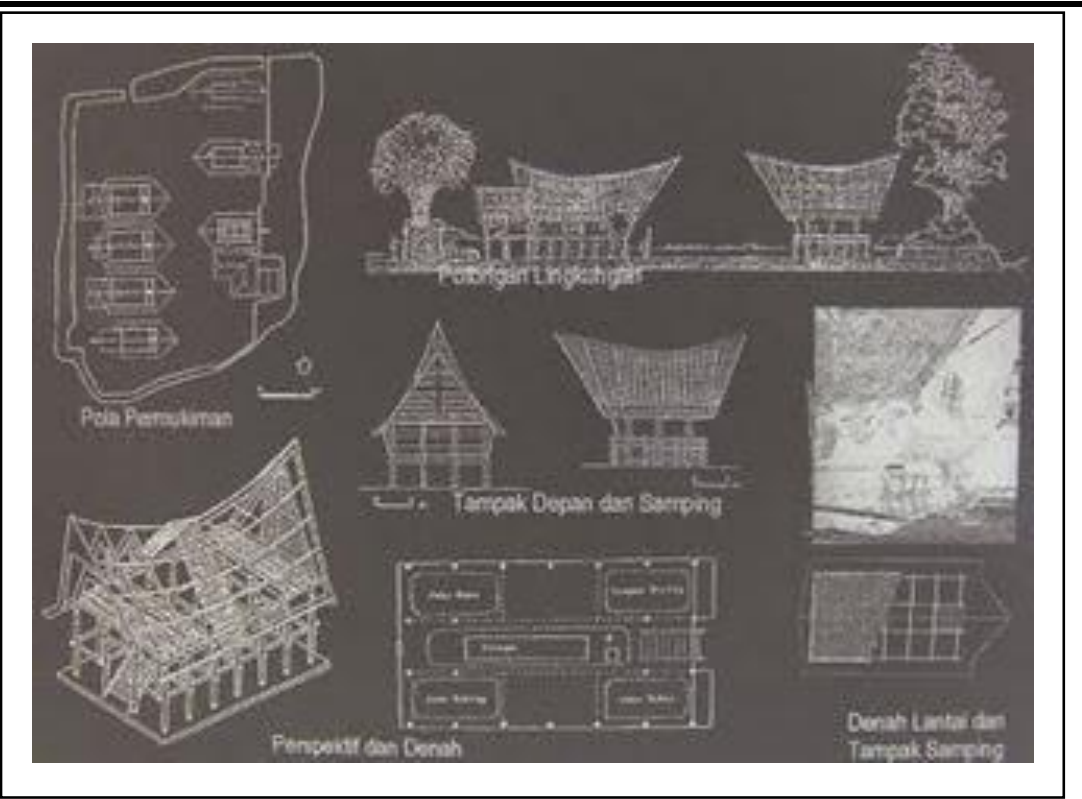

Sumber: diakses dari http://2.bp.blogspot.com, 2012

Gambar 3 Pola Perkampungan Tradisional Batak Toba Sebagai Simbol Kinship

Sumber: http://4.bp.blogspot.com (2012)

\section{Gambar 4 Pembagian Ruang Ruma Sebagai Simbol Kinship}

Interaksi dan hubungan kekerabatan yang erat dalam budaya masyarakat Batak Toba menjadi salah satu potensi sosial budaya lokal yang diadopsi dalam perancangan. Hal ini 
terutama dalam konsep tapak yang mengadopsi bentuk kampung dan menitikberatkan interaksi antar penghuni, konsep ruang yang banyak menempatkan ruang-ruang dengan aktivitas komunal baik pada bangunan maupun pada tapak, dan dan transformasi konsep ruma untuk bangunan hunian.

Konsep gotong royong dalam mendirikan kampung dan bangunan pada masyarakat tradisional Batak Toba adalah etos yang seharusnya dipertahankan dan dilestarikan serta menjadi potensi lokal yang harus dikembangkan. Hasil kuesioner menunjukkan bahwa $100 \%$ penduduk mendukung peningkatan dan perbaikan kualitas kawasan. Tingkat partisipasi ini dapat diterapkan dalam pembangunan dan pengelolaan Kawasan Wisata Tongging sebagai bentuk ikatan masyarakat terhadap kawasan wisata yang dibangun. Hal ini dapat diwujudkan antara lain melalui pemanfaatan tenaga kerja lokal dalam pembangunan dan pengembangan kawasan secara optimal, pengelolaan dan pengolahan sampah secara swadaya, pemanfaatan hasil-hasil pertanian sebagai bagian dari komoditas wisata, dan perbaikan lahan untuk fungsi konservasi.

Interpretasi hubungan kekerabatan (kinship) masyarakat Batak Toba dalam perancangan tata ruang kawasan akan membentuk simbiosis baru yang dicerminkan dalam program aktivitas, konsep ruang, dan konsep teknologi pada perancangan kawasan Wisata Tongging (Gambar 5).

\begin{tabular}{|c|l|l|}
\hline \multicolumn{2}{|c|}{ Masyarakat Tradisional Batak Toba } & \multicolumn{1}{c|}{ RTRK Tongging } \\
\hline \multirow{2}{*}{$\begin{array}{c}\text { Hubungan } \\
\begin{array}{c}\text { Kekerabatan } \\
\text { (Kinship) } \\
\text { sebagai pusat } \\
\text { interaksi sosial }\end{array}\end{array}$} & $\begin{array}{l}\text { Konsep struktur Huta dan } \\
\text { konsep rumah ruma merupakan } \\
\text { perwujudan kinship }\end{array}$ & $\begin{array}{l}\text { Konsep gotong royong dalam mendirikan bangunan dan kampung } \\
\text { aktivitas harian }\end{array}$ \\
\cline { 2 - 3 } & $\begin{array}{l}\text { Mengutamakan interaksi sosial antar penghuni sehingga tercipta ruang-ruang } \\
\text { komunal yang mewadahi interaksi sosial tersebut di tapak dan bangunan }\end{array}$ \\
\hline \multirow{2}{*}{ Program Aktivitas } & $\begin{array}{l}\text { Bentuk Simbiosis Baru } \\
\text { pemberdayaan masyarakat setempat melalui partisipasi aktif dalam } \\
\text { kerja lokal }\end{array}$ \\
\cline { 2 - 2 } & $\begin{array}{l}\text { Pemanfaatan teknologi berwawasan lingkungan dan berbasis sumber daya } \\
\text { lokal }\end{array}$ \\
\hline Konsep Ruang & $\begin{array}{l}\text { Konsep kampung pada tapak, dengan menerapkan fungsi-fungsi komunal } \\
\text { pada ruang-ruang publik }\end{array}$ \\
\hline
\end{tabular}

\section{Gambar 5 Interpretasi Terhadap Nilai Budaya Kekeluargaan Batak Toba}

\section{Agama kepercayaan dan Arsitektur Batak Toba}

Pengaruh Hindu memberikan konsekuensi kosmogoni, kosmologi, dan makrokosmos, mengubah pandangan Masyarakat tradisional Batak Toba terhadap rumah. Rumah menjadi refleksi keyakinan dan simbol mikrokosmos.

Anatomi rumah tradisional Batak Toba terbagi dalam tiga bagian. Struktur bawah adalah simbol dunia bawah dan kegelapan sebagai tempat kematian. Struktur bagian 
tengah adalah simbol tempat tinggal manusia, dan struktur bagian atas sebagai simbol dunia atas tempat Tuhan. Anatomi arsitektur tradisional Batak Toba dapat dilihat pada gambar 6.

Perubahan keyakinan dan Tuhan baru telah mengubah konsep rumah dalam pandangan masyarakat Batak Toba. Rumah tidak lagi mengacu pada kepercayaan. Lubis, dkk, 2004, menyampaikan bahwa perubahan ini telah menimbulkan suatu simbiosis yang baru, namun tetap familiar dengan masyarakat karena masih memiliki ikatan yang jelas dengan budaya yang lama, meskipun sesungguhnya tidak identik dan sama dengan budaya yang lama.

Anatomi bangunan vernakular Batak Toba sebagai bentuk apresiasi terhadap simbol agama dan kepercayaan yang pernah berkembang dalam masyarakat Batak Toba (sejarah budaya tempat), secara teknologi bangunan, merupakan bentuk yang adaptif terhadap iklim setempat. Dominasi bagian atap pada bangunan dengan bentuk yang curam, merupakan bentuk arsitektur tropis yang beradaptasi terhadap curah hujan dan kecepatan angin yang cukup tinggi. Dinding yang tipis dan ringan merupakan adaptasi terhadap tingkat kelembaban udara yang tinggi. Dinding hanya berfungsi untuk mencegah hujan dan angin. Konsep panggung (mengangkat bangunan dari atas permukaan tanah) memungkinkan terjadinya gerakan udara ke bawah bangunan yang akan menguntungkan ruang. Perbedaan temperatur tanah dan temperatur udara yang sedikit mengakibatkan pelepasan panas ke tanah tidak akan menguntungkan. Konsep panggung, secara ekologis, merupakan tindakan yang arif untuk tetap menjaga keberlangsungan penyerapan air ke tanah, dan menjaga aliran air dari dataran tinggi ke dataran rendah.

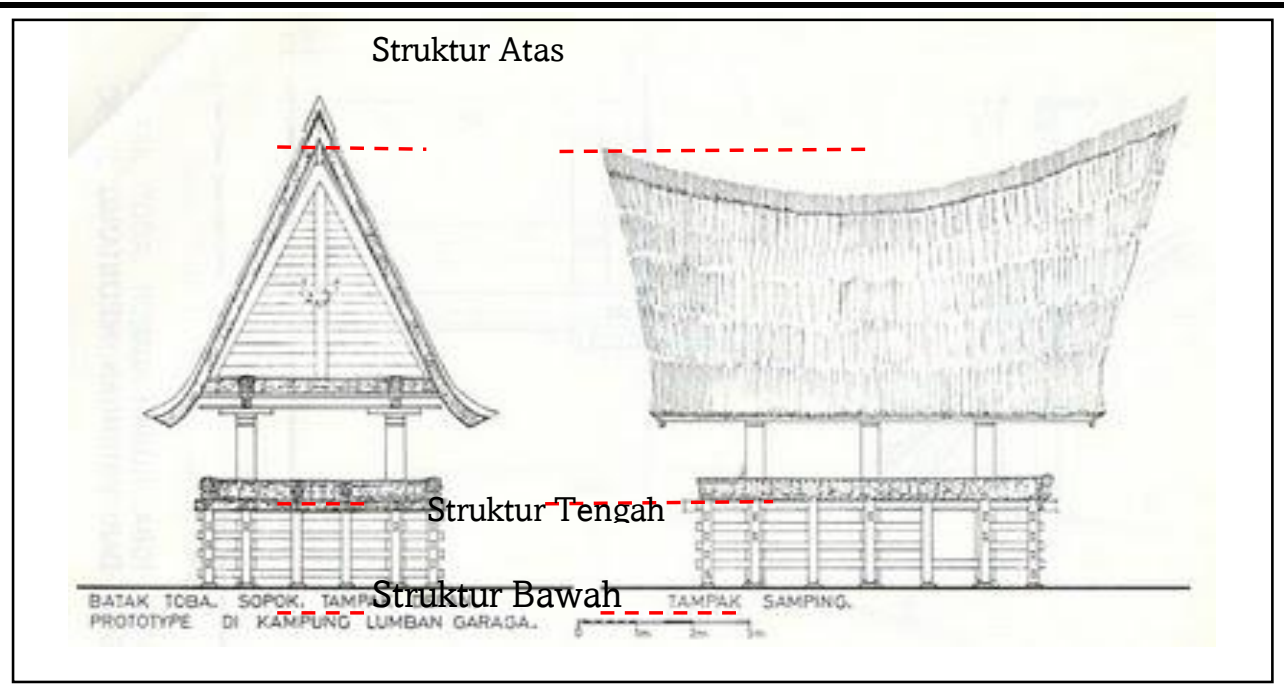

Sumber: diakses dari http://4.bp.blogspot.com, 2012

\section{Gambar 6 Anatomi Arsitektur Tradisional Batak Toba}

Anatomi bangunan tradisional Batak Toba yang adaptif terhadap iklim menjadi bentuk yang tetap dipertahankan sebagai anatomi bentuk bangunan di kawasan wisata Tongging. Sementara itu, orientasi bangunan tidak lagi berdasarkan hulu-hilir atau lautgunung, tetapi orientasi bangunan berdasarkan orientasi matahari dan potensi visual tapak, atas dasar kenyamanan ruang. Pemilihan bentuk ini didasarkan atas pertimbangan teknologi bangunan yang berwawasan lingkungan dan berorientasi pada lokal konteks. Hal ini menjadi dasar pertimbangan dalam hal pengembangan ide gagasan arsitektur dan bukan didasarkan pada trend globalisasi. Interpretasi agama dan kepercayaan sebagai dasar 
pandangan masyarakat tradisional Batak Toba dalam perancangan kawasan akan membentuk simbiosis baru yang diperlihatkan pada konsep bentuk, konsep tapak, dan konsep teknologi bangunan hotel (Gambar 7).

\section{Kesimpulan}

Identitas kawasan yang dapat dikembangkan sebagai dasar penataan ruang kawasan wisata di Desa Tongging sesuai interpretasi elemen vernakular Batak Toba diwujudkan melalui: 1) budaya agraris; 2) penataan ruang yang mengadopsi bentuk kampung; 3) budaya gotong royong melalui peningkatan partisipasi aktif masyarakat dalam perbaikan da peningkatan kualitas kawasan; dan 4) bentuk arsitektur tropis yang beradaptasi terhadap iklim.

Konsep rencana tata ruang kawasan menitikberatkan pada pengembangan potensi pertanian sebagai identitas utama kawasan. Pertanian menjadi orientasi utama pengembangan kawasan. Hal ini sesuai dengan prinsip pembangunan berkelanjutan yang dapat memberikan kesempatan ekonomi yang lebih baik dan meningkatkan harapan hidup penduduknya.

\begin{tabular}{|c|l|l|}
\hline \multicolumn{2}{|c|}{ Masyarakat Tradisional Batak Toba } & \multicolumn{1}{c|}{ RTRK Tongging } \\
\hline $\begin{array}{c}\text { Agama dan Kepercayaan } \\
\text { sebagai dasar pandangan } \\
\text { terhadap bangunan }\end{array}$ & $\begin{array}{l}\text { Konsep rumah didasarkan } \\
\text { pada konsekuensi } \\
\text { kosmogoni, kosmologi }\end{array}$ & $\begin{array}{l}\text { Konsep bangunan berorientasi pada } \\
\text { lokal konteks dan kenyamanan } \\
\text { penghuni }\end{array}$ \\
\hline \multicolumn{3}{|c|}{ Bentuk Simbiosis Baru } \\
\hline Konsep Bentuk & $\begin{array}{l}\text { Mempertahankan anatomi bentuk rumah tradisional Batak Toba sebagai } \\
\text { bentuk orientasi bangunan terhadap lokal konteks, terutama iklim dan kondisi } \\
\text { tapak. }\end{array}$ \\
\hline Konsep Tapak & Peletakan massa bangunan berorientasi pada potensi visual dan lokal konteks \\
\hline $\begin{array}{c}\text { Konsep } \\
\text { Teknologi }\end{array}$ & $\begin{array}{l}\text { Struktur bangunan panggung dipertahankan karena merupakan salah satu } \\
\text { usaha konservasi lahan dan air, selain untuk pengkondisian udara dalam ruang. }\end{array}$ \\
\hline
\end{tabular}

\section{Gambar 7 Interpretasi Nilai Budaya Agama dan Kepercayaan Batak Toba}

\section{Daftar Pustaka}

Frampton, Kenneth, 1983, Towards a Critical Regionalism: Six Point for an Architecture of Resistance, Bay Press

Maulana, Sherlly, 2010, Analisis Adaptasi Desain Bangunan Fasilitas Wisata Terhadap Elemen-elemen Regional dengan Menggunakan Teori Regionalisme Kritis untuk Meningkatkan Sense of Place Kawasan (Studi Kasus: Kawasan Wisata Danau Toba), Jurnal Semai Teknologi, UMA, Medan, No. 2 Volume 4, Desember 2010

Mohite, Amar, 2008, Geoffrey Bawa: An Understanding as A Critical Regionalist, Disertasi, (On Line), (http:www.amar-ujari.com diakses 21 Pebruari 2009)

Lubis, Nawawiy, dkk, 2004, Raibnya Para Dewa: Kajian Arsitektur Karo, Medan, Bina Teknik Press

Tzonis, Alezander and Liane Lefaivre, 2003, Critic Regionalism: Architecture and Identity in a Globalised World, Prestel Verlag, New York. 